\title{
Perceptions of Forest Owners and the General Public on the Role of Forests in Slovakia
}

\author{
Zuzana DOBSINSKA ${ }^{\mathrm{a}^{*}}-$ Zuzana SARVASOVA $^{\mathrm{b}, \mathrm{c}}$ \\ ${ }^{a}$ Department of Economics and Management of Forestry, Faculty of Forestry, \\ Technical University in Zvolen, Zvolen, Slovak Republic \\ ${ }^{\mathrm{b}}$ Department of Forest Policy, Economics and Forest Management, National Forest Centre - \\ Forest Research Institute in Zvolen, Zvolen, Slovak Republic \\ ${ }^{\mathrm{c}}$ Faculty of Forestry and Wood Sciences, Czech University of Life Sciences Prague, Prague, Czech Republic
}

\begin{abstract}
During the past decades, the awareness of environmental issues in forest management is increasing due to changes in environmental education. The perceptions of forests, sustainable management, and ecosystem services were studied through two surveys. The general public and forest owners were the two target groups. The questionnaires had similar questions, though two different methodological approaches were used - the CATI system, for general public opinion survey, and semi-structured questionnaires for forest owners. The second survey contained more detailed questions regarding forest properties. Combined answers from 1503 respondents from the general public and 150 forest owners were evaluated on the following topics: sustainable forestry, major ecosystem services, and perceptions of forests. The majority of the Slovakian public regards ecological values as the most important element, whereas forest owners prefer the economic purposes for the maintenance and enhancement of forests. Forest owners tend to visit their forests once per week, whereas the general public tend to visit only once per month. The main cause for this non-attendance in the general public was a lack of recreational time, followed by a disinterest in forests. The main purpose for visiting forests for both groups was recreation. Overall, it can be concluded that people are mostly satisfied with forest management in Slovakia. Forest owners are satisfied with their forest properties, and plan to keep them for their children. In the future, more attention should be focused on investigating the younger generation's perception of forests.
\end{abstract}

environmental education / forest functions / ecosystem services / forest management

Kivonat - Az erd tulajdonosok és a közvélemény felfogása az erd $k$ szerepér I Szlovákiában. Az elmúlt évtizedekben a környezet-tudatosság az erd gazdálkodásban emelkedett, amelyben a környezeti nevelésnek is szerepe van. Az erd $\mathrm{k}$, az erd gazdálkodás és az ökoszisztéma szolgáltatásokkal kapcsolatos felfogást két felmérés vizsgálta. A két célcsoportot a közvélemény és az erd tulajdonosok alkották. A kérd ívek hasonló kérdéseket tartalmaztak, bár két különböz módszertant alkalmaztak az ún. CATI rendszert a közvélemény esetében és a félig strukturált interjúkat az erd tulajdonosok esetében. Ez utóbbi részletes kérdéseket tartalmazott az erd tulajdonra vonatkozóan. A közvéleményt 1 származó 1503 , és az erd tulajdonosoktól származó 150 válasz összesített elemzése az alábbi témakörökre vonatkozóan történt: tartamos erd gazdálkodás, f bb ökoszisztéma szolgáltatások, és az erd kkel kapcsolatos felfogás. A szlovákiai nagyközönség többsége az ökológiai értékeket tekinti az

\footnotetext{
* Corresponding author: zuzana.dobsinska@tuzvo.sk, SK-96053, ZVOLEN, T. G. Masaryka 24
} 
erd k legfontosabb elemének, míg az erd tulajdonosok az erd k fenntartását és fejlesztését szolgáló gazdasági célokat részesítik el nyben. Az erd tulajdonosok az erd ket jellemz en hetente látogatják, a nagyközönség pedig havonta. Ez utóbbi okainak fontossági sorrendjében els helyen áll a kikapcsolódásra fordítható id hiánya, amelyet az erd kkel kapcsolatos érdektelenség követ. Mindkét csoport esetében az erd látogatás els dleges oka a kikapcsolódás. Összességében megállapítható, hogy az emberek többnyire elégedettek a szlovákiai erd gazdálkodással. Az erd tulajdonosok meg vannak elégedve az erd tulajdonukkal, és szándékaik szerint azt a gyerekeik számára hagyják örökül. A jöv ben nagyobb figyelmet szükséges fordítani a fiatal generációk erd felfogásának vizsgálatára.

\section{környezeti nevelés / erd k funkciói / ökoszisztéma szolgáltatások / erd gazdálkodás}

\section{INTRODUCTION}

The awareness of environmental issues in forest management is increasing due to changes in environmental education. According to the national strategy for environmental education adopted in 1996 (revised in 2006), the key factor in environmental education is education and training towards sustainable development. The so called "environmental minimum" contains the following topics: biodiversity maintenance, deforestation and soil erosion, rational use of natural resources, air, water and soil pollution, depletion of the ozone layer, acid rain, greenhouse effect, energy consumption, waste, urbanization, and population explosion (Izakovicova 2010). Forests are an essential component of the landscape and play an important role in environmental education.

Environmental education promotes positive attitudes, and is thus an important natural resource conservation tool. However, education strategies require urgent changes and innovative approaches to meet changing needs. In Slovakia, the persistent preference for teaching methods aimed at gaining verbal knowledge is still present, hindering the use of creative approaches. Pupils often gain theoretical knowledge without a complete understanding of the problems existing within their surrounding environment. They learn about global problems which are difficult to understand. The phenomena and processes occurring in the country are only studied in textbooks, without the possibility of monitoring these phenomena and processes directly.

Schools are an element in the process of change. Schools must promote active interaction among children, teachers, and parents. Future education strategies should start in the family, but must also be addressed in the classroom. Classic teaching approaches must be replaced by alternative methods which enable pupils to participate more actively, subsequently fostering the creativity of the pupil. The shift towards converting knowledge into conscious environmental behaviour is vital. It is necessary to examine people's fears and expectations for the future in order to understand how these perceptions of the future influence the way people behave, and how their current behaviour will influence the future (Hicks and Holden 1995).

Over the past few decades, significant changes have occurred in the views and demands on forests by society at large. This includes an increased level of environmental awareness and recreational interest in Slovakian society (Hajduchova - Sulek 2011). These changes also affect the public's perspective from the traditional role of forests as producers of raw materials. Simultaneously, the urge to re-orient societies towards increasingly "bio-based economies" results in a higher demand for raw material, not only for increasingly sophisticated products, but also for renewable energy (Rametsteiner et al. 2009).

Forests have acquired a new and more global meaning in modern society, going beyond their role as a productive and usable resource. For a growing portion of the population, forests represent a publicly-accessible space for recreation. At the same time, forests are increasingly identified as a natural environment. This new development reflects the needs and preferences of contemporary society, and the desire of an increasingly urban population for recreational 
opportunities in natural surroundings. It also reflects public concern over the impending threats to the environment and biodiversity. The wish to preserve a forest is evident in the number of demands for limiting forest exploitation and protecting areas in a close-to-natural state. For many people, the protection of environments and landscapes has become a major criterion for judging the overall performance of forest management strategies (Schmithusen 2007). Currently, a clear need exists to further develop the dialogue between the forestry sector and the general public in order to establish mutually acceptable relations (Lichý 2013).

These changes must also be reflected in forestry education. Forest education is changing in response to shifting international, national, and local perceptions towards forests (Stead 2001), and is necessary to meet the ever-changing needs of society. These needs include a worldwide commitment to sustainable forest management (SFM) and ecosystem-oriented approaches. In agreement with a change of perspective in the management of environmental issues, the process requested for SFM comprehends participatory mechanisms to involve relevant stakeholders (Kangas et al. 2006, Kangas et al. 2010). Therefore, there is an increased need for foresters to have communication skills which would enable them to interact at all levels: from local communities to government and international levels. Foresters should face this new paradigm using a bottom-up approach, rather than the top-down system that has previously characterized forest governance throughout the world - particularly with regards to forestry planning and stakeholder involvement. The bottom-up approach presents a two-way information flow system that considers prior consultation with target groups about their needs, problems, and aspirations for effective forestry planning. On the contrary, the topdown approach is simply a one-way information delivery system that reinforces the hierarchical relationship between the forester and the target group. These changes are not easy to implement or accept, and will require training in social relations in order to meet the growing demand of the public towards forests and their use - especially when it comes to a forest's recreation function (Kumar - Kant 2005). Foresters will no longer be sole agents of information and advice in these situations. Various interest groups such as environmental NGOs, citizens' associations, and municipalities all have an interest in promoting forest use.

The meaning of sustainable forest management has developed from its primary focus on wood production to include a wide range of different combinations of forest uses, meeting economic needs and opportunities while addressing dynamically changing social and cultural values (Schmithusen - Seeland 2006). This introduces new stakeholders into the forest policy-making process. These stakeholders arrive with their own perceptions, values, attitudes, and interests regarding forests and the forest sector (Krott 2005).

For this study, two stakeholder groups were analysed. One group includes the general public while the other group represents forest owners. The aim of this study is to present the results from these two surveys regarding the awareness of the general public and forest owners about forests, sustainable forest management, and ecosystem services.

\section{MATERIALS AND METHODS}

The perceptions of forests, sustainable management, and ecosystem services were studied by two surveys. The general public and forest owners were the two target groups, and the questionnaires had similar questions. The questions in the surveys were prepared with input from several experts in the field, including academics as well as forestry practitioners. The questionnaire for the general public opinion survey contained 10 questions. The semistructured questionnaire for forest owners contained 44 questions, including detailed questions regarding forest property. In total, answers from 1503 respondents (general public) 
and 151 forest owners were evaluated on following topics: sustainable forestry, major ecosystem services, and the perception of forests.

\section{General public survey}

The survey was carried out by a professional agency using the computer-assisted telephone interviewing (CATI) method. CATI is a telephone surveying technique in which the interviewer follows a script provided by a software application. This involves a structured system of data collection by telephone that speeds up the collection and editing of data, permitting the interviewer to educate respondents on the importance of timely and accurate data. The software is capable of customising the flow of the questionnaire based on the answers provided, as well as information already known about the participant.

The results of the public survey include responses collected between January and February 2013. In total, 1503 citizens were contacted via telephone, providing valid responses until February $28^{\text {th }}, 2013$. The age and residence distribution is shown in the Tables 1, 2, and 3.

\section{Forest owners' questionnaire}

The questionnaire for forest owners was sent via regular mail to 639 forest owners in June 2013. The target group was private forest owners - preferably members of forest owners associations from different regions of Slovakia. The sampling method represented convenience sampling, so it is therefore not a representative sample of all private forest owners in Slovakia. Therefore, the results must be interpreted with an appropriate level of caution. Respondents were selected using only one criterion defined by the research team: private forest ownership. Data collection was linked to ongoing research activities regarding private forest owners in Slovakia. The return rate was $23 \%$ (151) by November $10^{\text {th }}, 2013$. The age and residence distribution is shown in the Tables 3, 4 and 5.

Table 1. Gender distribution of respondents

\begin{tabular}{lcc}
\hline & $\begin{array}{c}\text { General } \\
\text { public }\end{array}$ & $\begin{array}{c}\text { Forest } \\
\text { owners }\end{array}$ \\
\hline Male & 777 & 137 \\
Female & 726 & 14 \\
\hline
\end{tabular}

Table 2. Residence distribution of respondents

\begin{tabular}{lcc}
\hline & $\begin{array}{c}\text { General } \\
\text { public }\end{array}$ & $\begin{array}{c}\text { Forest } \\
\text { owners }\end{array}$ \\
\hline Urban & 819 & 53 \\
Rural & 648 & 98 \\
\hline
\end{tabular}

Table 3. Age distribution of respondents

\begin{tabular}{lcc}
\hline & $\begin{array}{c}\text { General } \\
\text { public }\end{array}$ & $\begin{array}{c}\text { Forest } \\
\text { owners }\end{array}$ \\
\hline $18-24$ & 126 & 0 \\
$25-39$ & 385 & 6 \\
$40-54$ & 483 & 28 \\
$55+$ & 509 & 117 \\
\hline
\end{tabular}

In this study, seven questions (Q) were selected and evaluated. The questions are presented with answers (A) in Table 4. Questions were evaluated separately according to their order. The first portion of the questionnaires contained general questions relevant to further sampling, including age, gender, education, and residence. Q22 and 23 were asked only in the questionnaire aimed at forest owners. The answers of both surveys were compared and are presented in figures. Q22 and 23 were evaluated for urban and rural areas because the questions were asked only in the forest owner questionnaire. 


\section{Table 4. Selected evaluated questions}

\begin{tabular}{|c|c|c|c|}
\hline \multicolumn{2}{|c|}{ General Public Survey Questionnaire } & \multicolumn{2}{|c|}{ Forest Owners Survey Questionnaire } \\
\hline Q 4 & $\begin{array}{l}\text { People have different opinions on } \\
\text { why forests should be maintained } \\
\text { and enhanced. Which of the listed } \\
\text { options do you think should be the } \\
\text { most important in Slovakia? }\end{array}$ & Q 16 & $\begin{array}{l}\text { Which of the following options } \\
\text { explain the importance of owning a } \\
\text { forest for you? }\end{array}$ \\
\hline A & $\begin{array}{l}\text { Economic purpose, ecological } \\
\text { values, social aspects, other. }\end{array}$ & A & $\begin{array}{l}\text { Economic purpose, ecological values, } \\
\text { social aspects, other. }\end{array}$ \\
\hline Q 2 & How often do you visit a forest? & Q 18 & How often do you visit the forest? \\
\hline A & Once a week, once a month, never, & A & Once a week, once a month, never. \\
\hline Q 3a & $\begin{array}{l}\text { How do you spend your time in a } \\
\text { forest? For what purpose do you go } \\
\text { into a forest? }\end{array}$ & Q 19 & $\begin{array}{l}\text { How do you spend your time in the } \\
\text { forest? For what purpose do you go } \\
\text { into the forest? }\end{array}$ \\
\hline A & Recreational, NWFP, other. & A & Recreational, NWFP, other \\
\hline Q 3b & I do not go into a forest because: & Q 20 & I do not go into forest because: \\
\hline A & $\begin{array}{l}\text { I don't feel safe in a forest. } \\
\text { I have no time. } \\
\text { I am not interested in forests. }\end{array}$ & A & $\begin{array}{l}\text { I don't feel safe in the forest. } \\
\text { I have no time. } \\
\text { I am not interested in my forest. }\end{array}$ \\
\hline Q8 & $\begin{array}{l}\text { People have different opinions on } \\
\text { private forest management. In your } \\
\text { opinion rate, as in school using a } \\
\text { score from } 1 \text { to } 5 \text {, how well do } \\
\text { private forest owners and their } \\
\text { associations take care of their forest } \\
\text { property (with one being the best } \\
\text { and five being the worst)? }\end{array}$ & Q 21 & $\begin{array}{l}\text { Rate how private forest owners and } \\
\text { their associations take care of their } \\
\text { forest properties. }\end{array}$ \\
\hline \multirow[t]{5}{*}{ A } & $1,2,3,4,5$ & A & $1,2,3,4,5$ \\
\hline & & Q 22 & $\begin{array}{l}\text { What are your plans for your forest } \\
\text { property in the future? }\end{array}$ \\
\hline & & A & $\begin{array}{l}\text { Sell, lease, leave for children, expand, } \\
\text { buy new forests, no plans, other. }\end{array}$ \\
\hline & & Q 23 & $\begin{array}{l}\text { How do you evaluate your forest } \\
\text { property in terms of your expectations? }\end{array}$ \\
\hline & & A & Satisfied, not satisfied, don't know. \\
\hline
\end{tabular}

\section{RESULTS}

An important factor influencing public perception of forests in Slovakia is the right to free access to forests guaranteed by the Forest Act. This implies that visitors are permitted to walk, ski, or cycle on another person's land, as long as landowners' and/or public peace is not disturbed, and fields or plantations are not damaged. In Q4 and Q16, the general public and 
forest owners were asked about what the main purpose of forests should be. The majority of the public regards ecological values as the most important (1258 out of 1503), whereas forest owners prefer an economic purpose (83 out of 151).

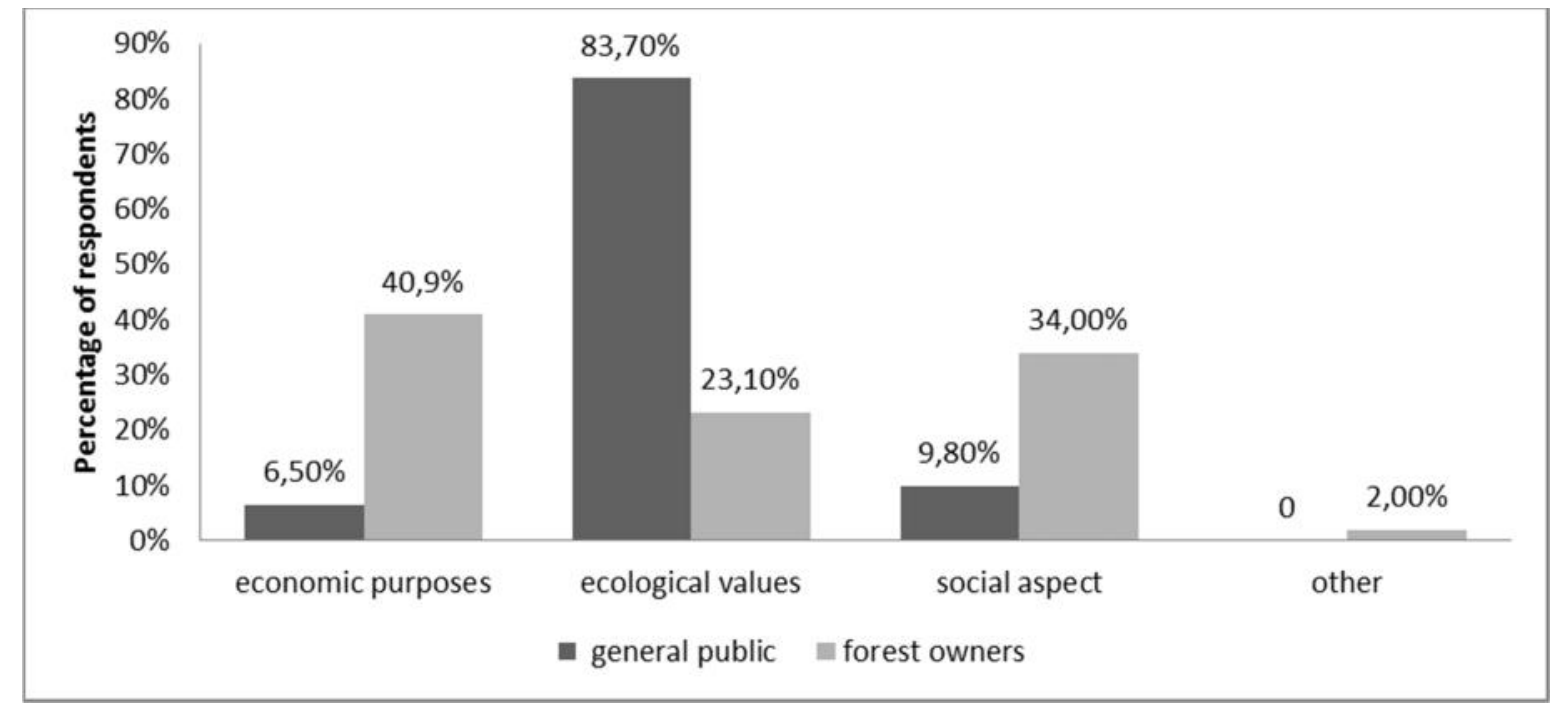

Figure 1. The purposes of maintaining and enhancing forests

The frequency of forest attendance is evaluated in Figure 2. The majority of the general public visits a forest once a month $(63.41 \%, 541)$, whereas forest owners visit their forest weekly $(74.17 \%, 112)$. Respondents who do not visit forests at all were mainly from the general public category (122), compared to only one forest owner.

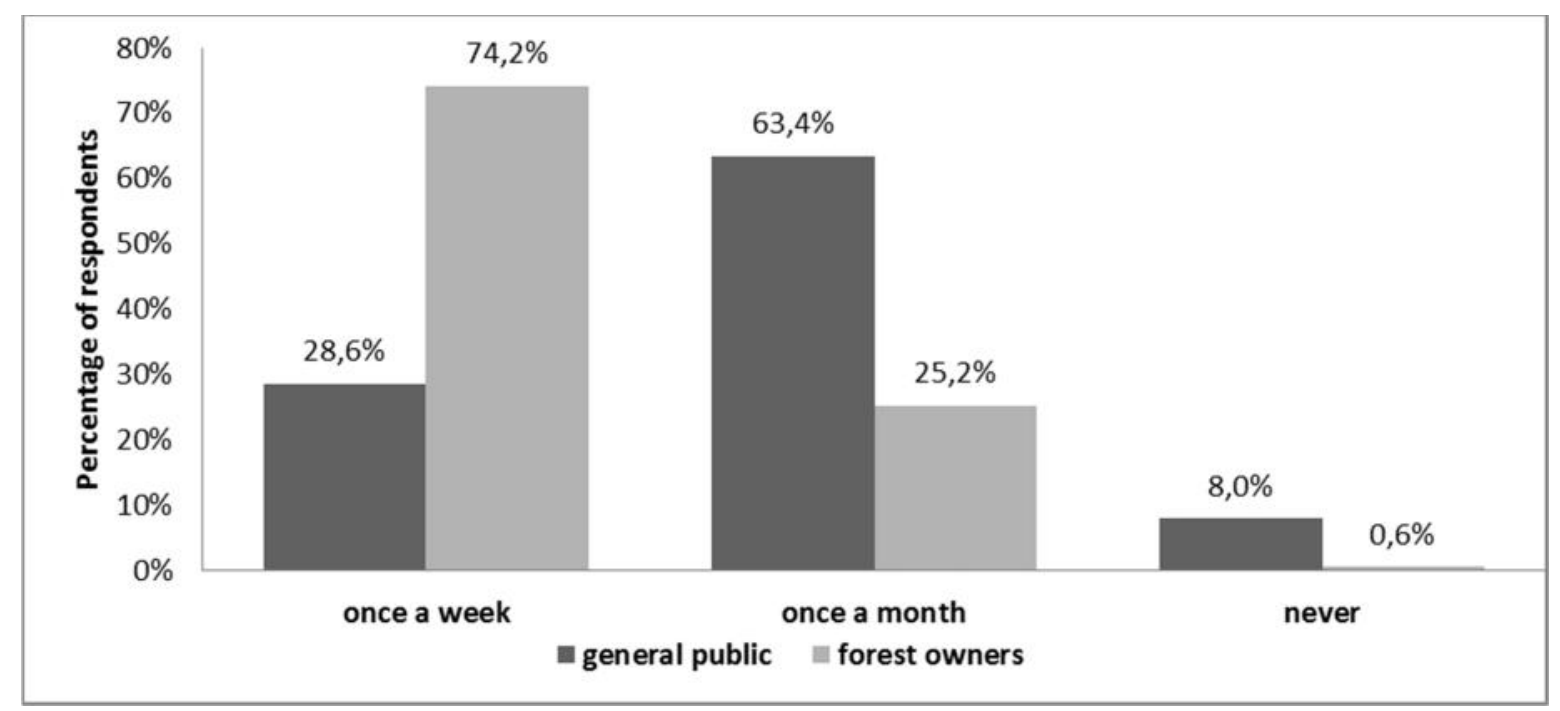

Figure 2. Frequency of forest attendance

The next question is built upon the previous one. When a respondent replied that they never visit forests, they were asked the reason why. The main reason for non-attendance was a lack of free time (68) followed by a lack of interest in forests (46). Only 6\% of the general public does not feel safe in forests (Figure 3). 


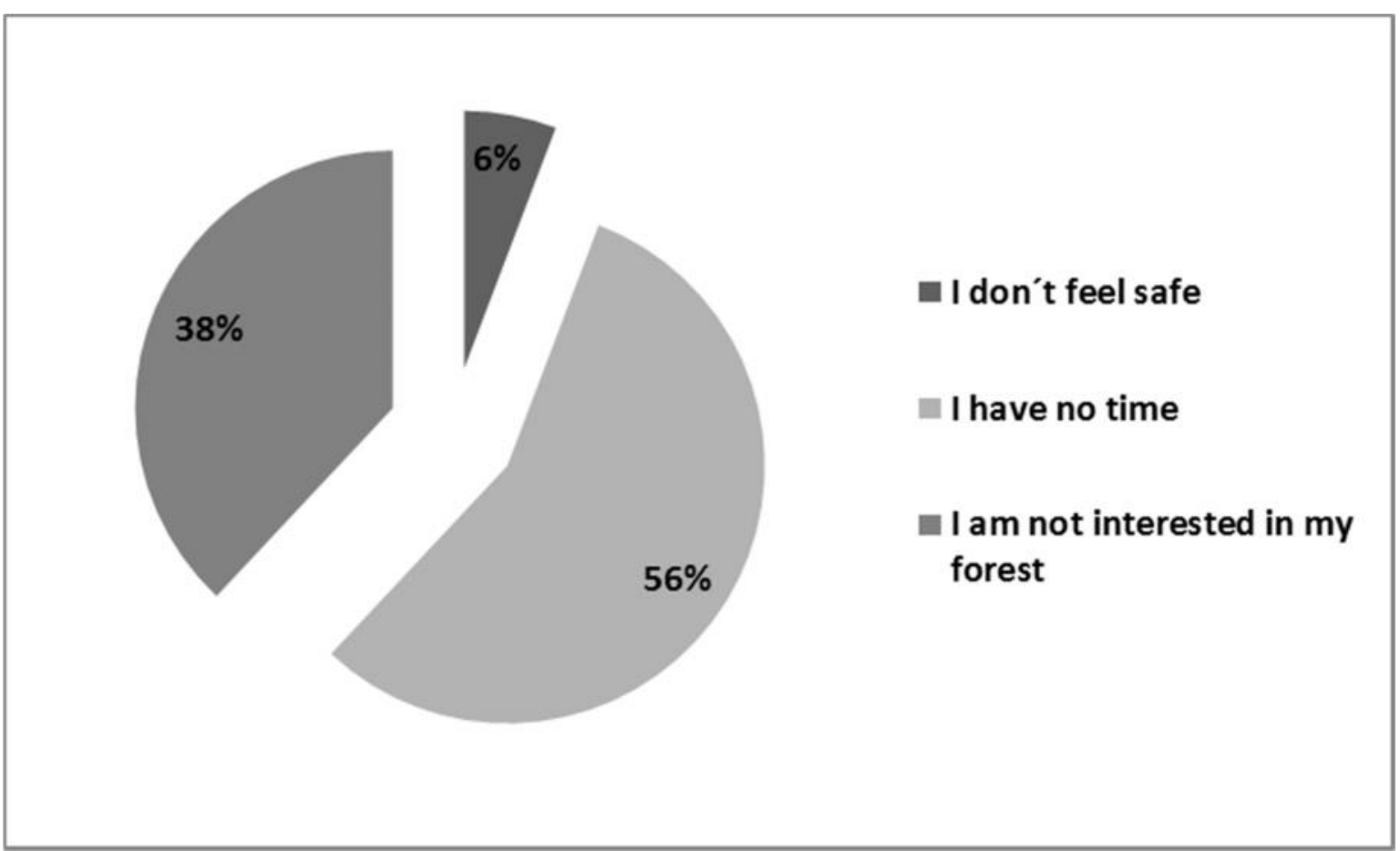

Figure 3. Reasons for not visiting a forest in the general public group

Forests provide a variety of ecosystem services. This question investigated the hierarchy of ecosystem services as perceived by the respondents. The primary purpose for visiting forests for both groups was recreation $(79.87 \%$ of the public and $68.70 \%$ of forest owners), followed by non-wood forest products (Figure 4). The recreational category included the following activities: tourism, sport, rest, and hunting.

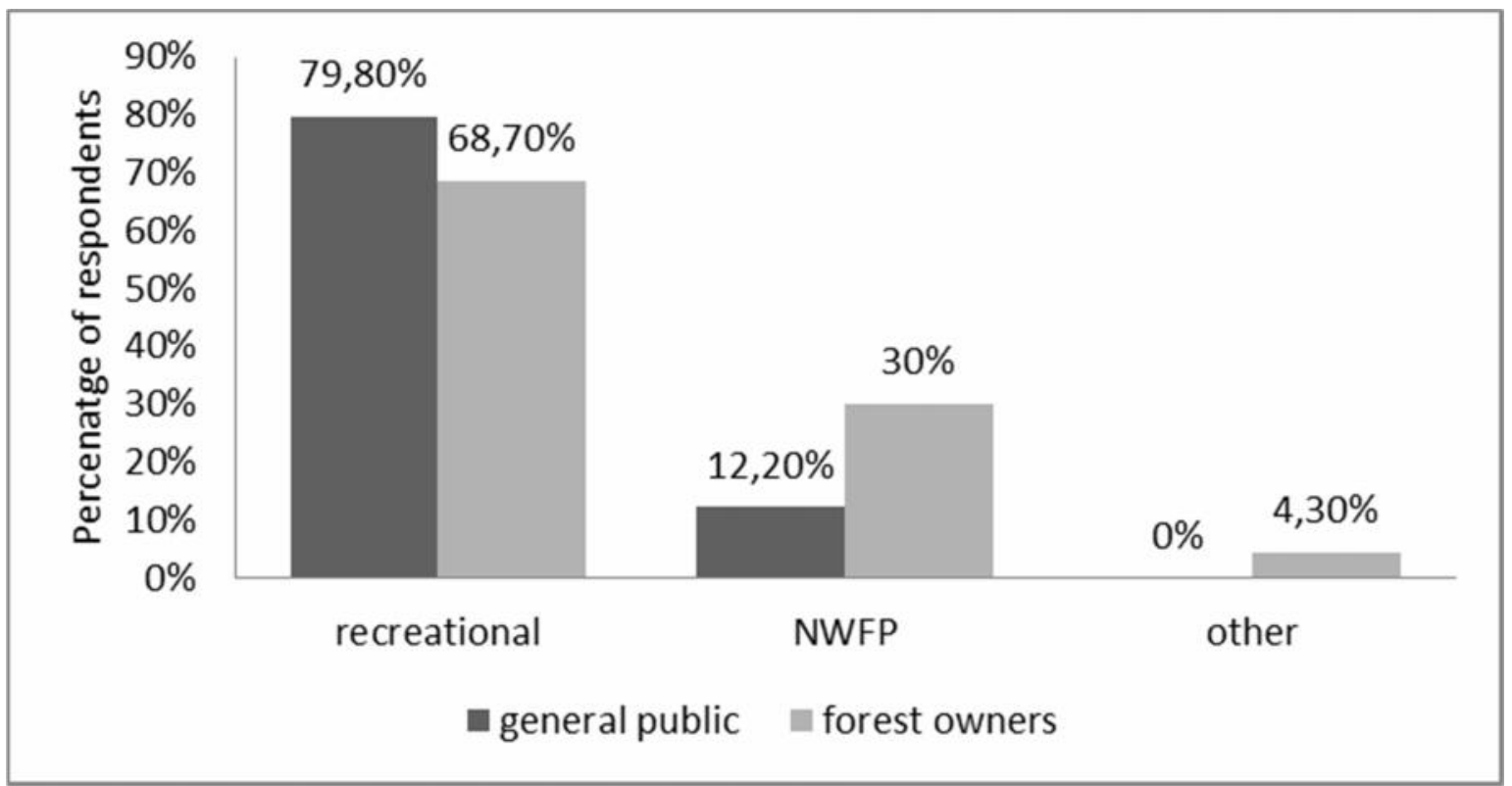

Figure 4. Main ecosystem services that forests should provide 
In $\mathrm{Q} 8 / 21$, respondents could rate the forest management conducted by private forest owners. The grading scheme is the same as that of the Slovakian school system, where a score of 1 represents the best and a score of 5 represents the worst. Most of the general public rated the private forest owners with a score of 2 or 3 . Most private forest owners marked their management with a score 2 , followed by 1 and 3 .

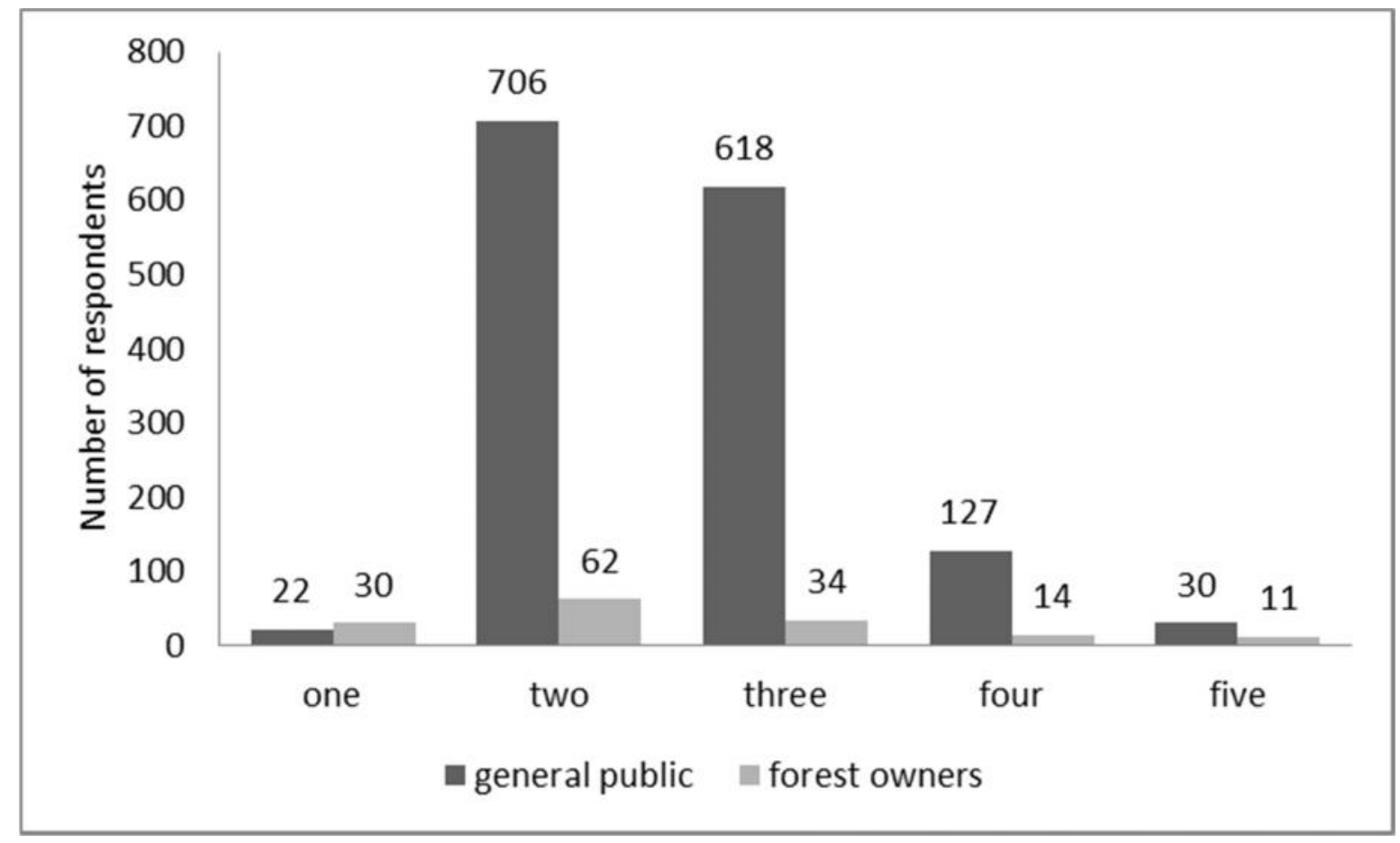

Figure 5. How are private forest owners managing their forests?

The two final questions were asked only in the forest owner questionnaire. The questions regarded the respondents' own forest properties. Table 6 illustrates future forest property plans. The majority of forest owners intend to leave their property for their children.

Table 6. Future plans for forest properties

\begin{tabular}{lccccccccccccc}
\hline & \multicolumn{2}{c}{ Sell } & \multicolumn{2}{c}{ Lease } & \multicolumn{2}{c}{$\begin{array}{c}\text { Leave } \\
\text { for children }\end{array}$} & \multicolumn{2}{c}{$\begin{array}{c}\text { Buy } \\
\text { new forests }\end{array}$} & \multicolumn{2}{c}{ No plans } & \multicolumn{2}{c}{ Other } \\
\cline { 2 - 15 } & Total & $\%$ & Total & $\%$ & Total & $\%$ & Total & $\%$ & Total & $\%$ & Total & $\%$ \\
\hline Urban areas & 1 & 1.9 & 2 & 3.8 & 31 & 58.5 & 13 & 24.5 & 0 & 0 & 6 & 11.3 \\
Rural areas & 0 & 0 & 3 & 3.1 & 66 & 67.3 & 23 & 23.5 & 2 & 2 & 4 & 4.1 \\
\hline
\end{tabular}

Most forest owners are satisfied with their property (Table 7). The ownership of forested land meets their expectations. In rural areas, owners are more satisfied with their property when compared to owners living in urban areas.

Table 7. Expectations of the owned forest property

\begin{tabular}{lcccccc}
\hline & \multicolumn{2}{c}{ Satisfied } & \multicolumn{2}{c}{ Discontent } & \multicolumn{2}{c}{ Don't know } \\
& Total & $\%$ & Total & $\%$ & Total & $\%$ \\
\hline Urban areas & 43 & 81.1 & 3 & 5.7 & 7 & 13.2 \\
Rural areas & 78 & 79.6 & 11 & 11.2 & 9 & 9.2 \\
\hline
\end{tabular}




\section{DISCUSSION}

Regarding the validity of the research findings, it has to be stated that although the study includes a large sample of the general public population, the questionnaire may have included biases in the selection of respondents. The use of CATI for selection criteria aims at randomizing selection as much as possible, though it presents possible deficiencies (e.g. some people might not have been registered or included in the register). The survey conducted on forest owners is not representative as respondents were selected purposively, so the results must be approached with caution as they are unlikely to be representative of the whole country. However, these results provide valuable insight into the perceptions of forest owners.

The main purpose for visiting forests in Slovakia corresponds to similar research conducted in this area (Rametsteiner et al. 2009), which suggested that the European public places a higher value on forest conservation and the protective functions of forests rather than on forest utilisation aspects. This contrasts forest owners, whose main concern is the economic profit from their property. Public opinion on the productive functions of forests has been studied in many European countries. Previous studies conclude that the general public in typical forestry countries such as Sweden, Norway, or Austria seem to have a more sensitised, pragmatic, and balanced view of the productive functions of forests with regards to the interplay between humans and nature. The general public of eastern and southern Europe tends to view forest functions more from the amenity perspective. In the majority of countries, the public mentioned recreational, educational, and scientific purposes as positive forest functions, while extensive logging, hunting, and construction were generally regarded as negative forest-related activities (Rametsteiner et al. 2009). An overwhelming majority of people in central Europe, for example, link the economic function of forests mainly to the production of wood. In Finland, most private forest owners indicate that financial profit is still important, but they simultaneously classify the recreational uses and aesthetic experiences provided by their forests as almost equally important (Heino - Karvonen 2003).

When it comes to visiting forests, not many of the surveys carried out in Europe asked people how often they did this. In Germany a nationwide quantitative survey concerning forests and forestry was conducted in 2007. In it, $49 \%$ of the respondents stated enjoying a visit to a forest. In contrast, only $19 \%$ of the questioned German public stated that forests are not interesting for them (Kleinhückelkotten - Wipperman 2007). Of the respondents in Lithuania who had visited forests, $25 \%$ said that they visited at least 3-4 times per year (Mizaraite - Mizaras 2006).

With regard to forest attendance, the results in other European countries are similar to this Slovakian survey. In Germany, $77 \%$ of interviewees view the forest as a place for recreation and relaxation; 55\% used the forests for recreational walks. Other activities included observing nature (42\%), collecting herbs $(20 \%)$, having barbeques and parties (17\%), as well as jogging and 'Nordic walking' (17\%) (Kleinhückelkotten - Wipperman 2007). A survey from the Czech Republic stated that the collection of non-wood forest products, such as mushrooms and different kinds of berries, had a high recreational value for visitors (Šišák 2006). The most popular forest activities among Swiss citizens were recreation and various types of sports, followed by the gathering of non-wood forest products (Seeland et. al 2007). Interestingly, in the study conducted by Rametsteiner et al. (2009), recreational purposes were not ranked as one of the top two most important benefits by European citizens. This contradicts previous studies, as well as the expectations of forest experts across Europe (Rametsteiner et al. 2009).

Ecosystem services tend to be more important for people living in central Europe $(10.1 \%$ rank them as most important element) when compared to other regions. They are considered least important by people in north-western European countries (3.8\%). A high variation in in 
results can be found within individual countries. Approximately $16 \%$ of people in Slovakia rank ecosystem services as most important, followed by Finland (15.3\%), and Slovenia (Rametsteiner et al. 2009).

With the development of new environmental education strategies in Slovakia, there is a need to conduct opinion surveys of young people as a target group. Research in other countries which has targeted young people has shown that perceptions, attitudes, and knowledge should represent key components in the preparation of programmes for community education, forest resource management, and conservation (Barrazza - Pineda, 2003).

\section{CONCLUSIONS}

Slovakia appears to contrast other countries in its inability to face the challenge of creating general acceptance for the forestry sector. In most developed countries, ecological values are becoming more prevalent among the general population, though they are not as evident among private forest owners. Results suggest that people are mostly satisfied with the management of forests in Slovakia. As the results of the public survey have indicated, the general public has expectations with regards to forests and forestry, expecting greater protection and management for ecosystem services (emphasising on ecological values before economic purpose), contrary to forest owners, who stress the economic function.

In the future, younger generations must work to improve their knowledge of forestry and forests. The implementation of educational programs prepared for schools that include elements of forest education support these findings.

In surveys that will take place in the coming years, changes in perceptions on ecosystem services and higher trust in foresters are expected.

Acknowledgements: This work was supported by the Slovak Research and Development Agency under contract No. APVV-0057-11, and the Czech Agency for Agricultural Research under contract No. QJ1220313. This publication was implemented as a result of: Centre of Excellence "Decision support in forest and country", ITMS: 26220120069, and supported by the Research \& Development Operational Programme funded by the ERDF.

\section{REFERENCES}

BARRAZA, L. - PINEDA, J. (2003): How young people see forests in Mexico: a comparison of two rural communities, Unasylva 213(54): 10-17.

HAJDUCHOVA, I. - SULEK, R. (2011): Forests - key development factor of selected regions in Slovakia. In Resources of the Slovak Republic as a factor of development strategies in European and global space. Bratislava: Ekonóm.

HEINO, J. - KARVONEN, J. (2003): Forests - an integrated part of Finnish life. Unasylva 213(54): 3-9.

HICKS, D. - HOLDEN, C. (1995): Visions of the future: why we need to teach for tomorrow. London, Trentham Books.

IZAKOVICOVA, Z. (2010): Nové netradičné formy environmentálnej výchovy (New Untraditional Forms of Environmental Education). Geographia Cassovienensis 2: 22-26.

KANGAS, A. - LAUKKANEN, S. - KANGAS, J. (2006): Social choice theory and its applications in sustainable forest management-a review. Forest Policy and economics, 9(1): 77-92.

Kangas, A. - SAarinen, N. - SAarikoski, H. - Leskinen, L. A. - Hujala, T. - Tikkanen, J. (2010): Stakeholder perspectives about proper participation for Regional Forest Programmes in Finland. Forest Policy and Economics, 12(3): 213-222. 
KLEINHÜCKELKOTTEN S. - WIPPERMANN C. (2007): Kommunikation für eine nachhaltige Waldwirtschaft in Deutschland [Communication for a Sustainable Forest Economy in Germany]. In: Berichtsband zum 39. Forstpolitikertreffen, Tschechische Landwirtschaftliche Universität in Prag, Fakultät für Forstwirtschaft und Umwelt, Prag (in German).

KrotT, M. (2005): Forest Policy Analysis. Springer, 323 p.

KUMAR, S. - KANT, S. (2005): Bureaucracy and new management paradigms: modelling foresters' perceptions regarding community-based forest management in India. Forest Policy and Economics 7: 651-669.

LICHÝ, J. (2013): Proposal of model of forest enterprise media communication. Lesnícky časopis Forestry Journal, 59(4): 276-283, 2013, ref. 30, ISSN 0323 - 1046.

MiZARAITE, D. - MiZARAS, S. (2006): Afforestation of agriculture land as a tool of rural forestry development in Lithuania. In: Wall, S. (ed.). 2006. Small-scale forestry and rural development: the intersection of ecosystems, economics and society. Proceedings of the IUFRO 3.08 conference hosted by Galway-Mayo Institute of Technology, Galway, Ireland. Online http://www.fao.org/fileadmin/user_upload/rome2007/docs/Afforestation_agriculture_land_Lithua nia.pdf.

RAMETSTEINER, E. - EICHLER, L. - BERG, J. (2009): Shaping forest communication in the European Union: public perceptions of forests and forestry. Final report. Online $\mathrm{http} / / /$ forestindustries.eu/sites/default/files/userfiles/1file/Shaping_forest_communication.pdf

SCHMITHUSEN, F. (2007): Multifunctional forestry practices as a land use strategy to meet increasing private and public demands in modern societies. Journal of Forest Science 53 (6): 290-298.

SCHMithusen, F. - SEELAND, K. (2006): European Landscapes and Forest as Representation of Culture. In: Cultural Heritage and Sustainable Forest Management - The Role of Traditional Knowledge. Ministerial Conference on the Protection of Forests in Europe, Liaison Unit, Warsaw, 1: 217-224.

SEElAND, K. - Kilchling, P. - HANSMANN, R. (2007): Urban consumers' attitudes towards nonwood forest products and services in Switzerland and an assessment of their market potential. Small-scale Forestry (6): 443-452.

SISAK, L. (2006): Importance of non-wood forest product collection and use for inhabitants in the Czech Republic. Journal of Forest Science 52(9): 417-426.

STEAD, J. (2001): Requirements of a forestry education from an ENGO perspective. In Meeting of Iinternational University Forestry Education Leaders. 4 December 2001. Vancouver, BC, Canada. University of British Columbia Faculty of Forestry/FAO. 
